Jap. J. M. Sc. \& Biol., 14, 263-267, 1961

NOTE

\title{
ON THE DIFFERENCE BETWEEN THE TOXIGENICITY AND INFECTIVITY OF C. DIPHTHERIAE
}

In the previous paper it was shown that the infectivity at the mucous membrane of the $C$. diphtheriae was different from the toxigenicity (Murata et al., 1959). Some additional data are presented here to show these different characteristics of this organism.

\section{Experimentals.}

Three strains were chosen in this experiment. Strain 10-19 invariably developed a severe disease and strain 8-14 a mild case. Strain PW-8 was chosen because of its high toxigenicity in the fluid media, but it caused very slight clinical symptoms by conjunctival method.

Exp. 1. Bacterial suspensions of three strains were prepared by washing twice fresh cultures from serum agar plates. To test the lethal activity, adequate two-fold serial dilutions of the suspensions were injected into guinea pigs $(350-450 \mathrm{~g})$ subcutaneously in a volume of $1 \mathrm{cc}$. DRM was determined by intracutaneous injection of serial dilutions in a volume of $0.1 \mathrm{cc}$ on the back of guinea pigs. The sensitivity of the skin to diphtheria toxin was checked by intracutaneous injection of 10 to 80 fold dilutions of Schick toxin. Infection at the conjunctiva was carried out by the same method as before by using a bacterial suspension of $30 \mathrm{mg}$ per cc by wet weight (Murata et al., 1959).

The results are shown in Table 1. Autopsy of animals which died showed typical changes of intoxication in all cases irrespective of the methods of infection. It was then examined whether the intoxication after injection of cell suspension was caused by the toxin involved in the original cells or produced in vivo. The suspensions of washed cells of strain 10-19 were injected subcutaneously to two groups of guinea pigs. One group of them received simultaneously the intravenous injection of $6 \mathrm{mg}$ erythromycin and then the subcutaneous injection of $2 \mathrm{mg}$ of the drug for subsequent 4 days. Almost all animals of the control groups (9/10) (without erythromycin) died within 3 days after injection, while animals of erythromycin group survived for a period during which they were treated with the drug but all died after the treatment was discontinued (Table 2). This fact and the pathological changes on autopsy suggest that the intoxication might be due to the toxin produced de novo after injection. In other words, the injection method shows the toxigenicity in vivo.

Toxigenicity in vivo was almost equal with three strains by intracutaneous or subcutaneous method, while significant differences were shown in the conjunctival method. These results suggest that there are fundamental difference between the infectivity by mucous membrane method and the toxigenicity by the injection.

Exp. 2. Mueller (1941) reported that the virulent gravis type strain was able to produce a high titer toxin in the medium with high iron concentration. Then an ex- 
periment was performed to compare the toxin production of three strains under various iron concentrations. Toxin production was tested with three liquid media commonly used by varying their iron concentration from 0.1 to $6.4 \mu \mathrm{g}$ per $\mathrm{cc}$. These media

Table 1. Comparison of virulence of Corynebacterium diphtheriae by three different methods

\begin{tabular}{|c|c|c|c|c|c|c|c|c|c|c|}
\hline \multirow{3}{*}{$\begin{array}{l}\text { Exp. } \\
\text { No. }\end{array}$} & \multirow{3}{*}{$\begin{array}{l}\text { Strains } \\
\text { used }\end{array}$} & \multicolumn{7}{|c|}{ Lethal activity by subcutaneous method } & \multirow{3}{*}{$\begin{array}{l}\text { Toxic activity } \\
\text { by } \\
\text { intracutaneous } \\
\text { method* }\end{array}$} & \multirow{3}{*}{$\begin{array}{c}\text { Grade of } \\
\text { severity of the } \\
\text { disease by } \\
\text { conjunctival } \\
\text { method }\end{array}$} \\
\hline & & \multicolumn{7}{|c|}{$\begin{array}{l}\text { Dilutions of bacterial suspension } \S \\
\text { Injection vol. : } 1 \mathrm{cc}\end{array}$} & & \\
\hline & & $16 \mathrm{x}$ & $32 \mathrm{x}$ & $64 \mathrm{x}$ & 128 & $\mathrm{x}$ & 256 & $\mathrm{x}$ & & \\
\hline \multirow[t]{3}{*}{1} & $10-19$ & & $\mathrm{~S}$ & $\mathrm{~S}$ & $\mathrm{~S}$ & & $\mathrm{~S}$ & & 3,200 & severe \\
\hline & $8-14$ & & $\mathrm{D}_{4}$ & $\mathrm{D}_{4}$ & S & & $\mathrm{S}$ & & 12,800 & mild \\
\hline & PW- 8 & & $\mathrm{D}_{4}$ & $\mathrm{D}_{4}$ & $\mathrm{~S}$ & & S & & 25,600 & mild \\
\hline 2 & $10-19$ & $\mathrm{D}_{1} \quad \mathrm{D}_{1}$ & $\mathrm{D}_{5} \quad \mathrm{D}_{6}$ & $\mathrm{D}_{2}$ & $\mathrm{~S}$ & $\mathrm{~S}$ & $\mathrm{D}_{10}$ & $\mathrm{~S}$ & 6,400 & severe \\
\hline \multirow[t]{2}{*}{3} & $8-14$ & $\mathrm{D}_{1} \mathrm{D}_{1}$ & $\mathrm{D}_{1} \quad \mathrm{D}_{2}$ & $\mathrm{D}_{4} \quad \mathrm{D}_{4}$ & $\mathrm{D}_{6}$ & $\mathrm{~S}$ & & & 25,600 & mild \\
\hline & $10-19$ & $D_{2} \quad D_{2}$ & $\mathrm{D}_{2} \quad \mathrm{D}_{3}$ & $\mathrm{D}_{4} \quad \mathrm{~S}$ & $\mathrm{~S}$ & $\mathrm{~S}$ & S & $\mathrm{S}$ & 12,800 & severe \\
\hline \multirow[t]{2}{*}{4} & $10-19$ & $D_{1} \quad D_{2}$ & $\mathrm{D}_{2} \quad \mathrm{D}_{3}$ & $\mathrm{D}_{4}$ & $\mathrm{D}_{10}$ & S & $\mathrm{S}$ & $\mathrm{S}$ & 12,800 & severe \\
\hline & PW- 8 & $\mathrm{D}_{1} \quad \mathrm{D}_{1}$ & $\mathrm{D}_{2} \quad \mathrm{D}_{2}$ & $\mathrm{D}_{3} \quad \mathrm{D}_{6}$ & $\mathrm{~S}$ & S & $\mathrm{S}$ & $\mathrm{S}$ & 12,800 & mild \\
\hline
\end{tabular}

$\S$ : Bacterial suspension contained $0.33 \mathrm{mg}$ bacterial nitrogen per cc.

* : Figures show the highest dilution of the bacterial suspension which show the minimal reaction of $9-10 \mathrm{~mm}$.

D : Died, the figures show the death time in days.

S: Survived 14 days after injection.

Table 2. Effect of erythromycin in the toxigenicity test of Corynebacterium diphtheriae

\begin{tabular}{|c|c|c|c|}
\hline Treatment & $\begin{array}{l}\text { Amount of organism } \\
\text { inoculated (mg N) }\end{array}$ & Survival & in days \\
\hline \multirow{5}{*}{$\begin{array}{l}\text { Animals given with } \\
\text { erythromycin }\end{array}$} & 0.002 & 5 & 6 \\
\hline & 0.006 & 8 & 9 \\
\hline & 0.02 & 4 & 9 \\
\hline & 0.06 & 5, & 6 \\
\hline & 0.18 & 6 & 11 \\
\hline \multirow{5}{*}{ Control (no erythromycin) } & 0.002 & 3 & 5 , \\
\hline & 0.006 & 2 , & 3 \\
\hline & 0.02 & 1 , & 1, \\
\hline & 0.06 & 1 & 2 \\
\hline & 0.18 & 1, & 2 \\
\hline
\end{tabular}

were Pope's peptone medium, Martin's broth and Mueller and Miller's semisynthetic medium slightly modified by the authors. The inoculated media were incubated at $34^{\circ} \mathrm{C}$ for 7 days. Toxin was expressed in terms of DRM determined by the intracutaneous rabbit method. An example of the results is shown in Fig. 1. Since three strains showed a similar behavior to the change of iron concentration in all media, it 


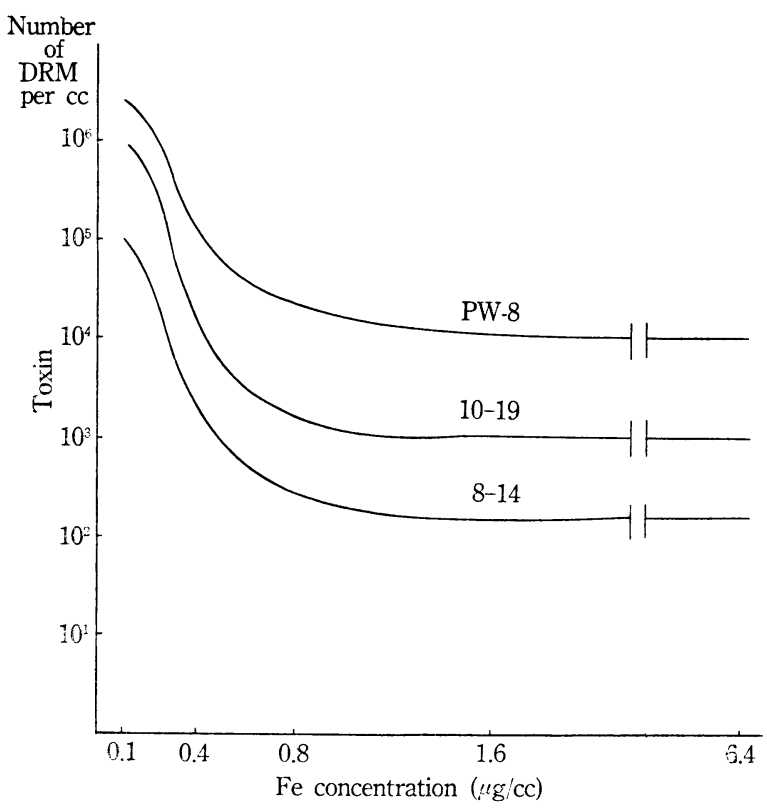

Fig. 1. Toxin production by three strains in the peptone medium under various iron concentrations.

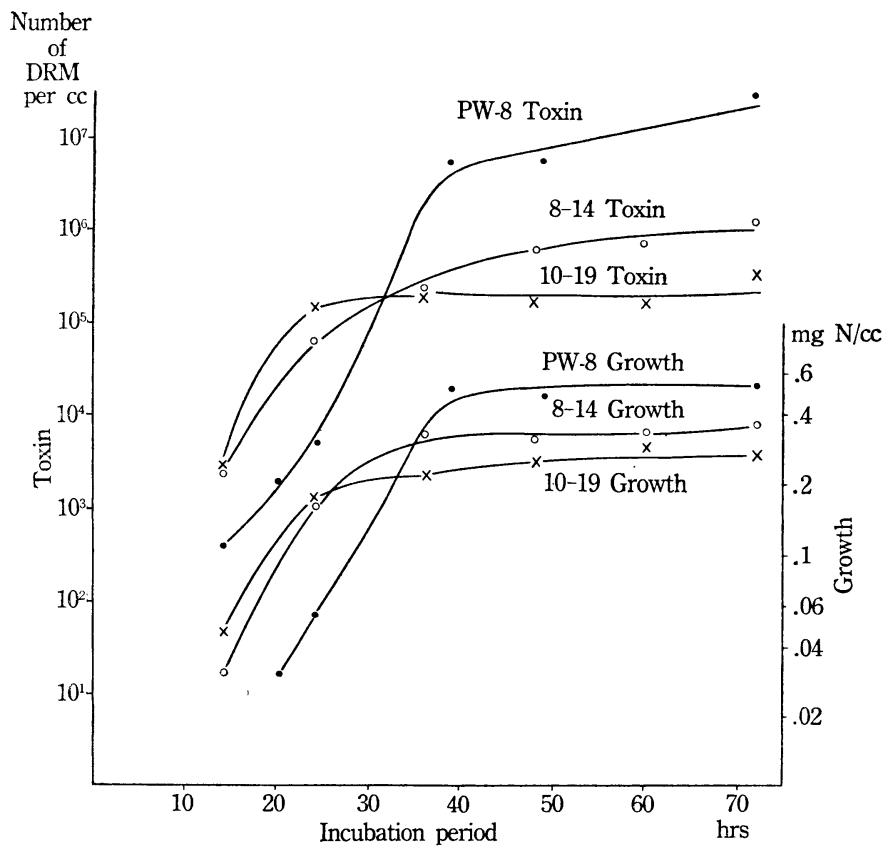

Fig. 2. Growth and toxin production of three strains in the semisynthetic medium (I). 


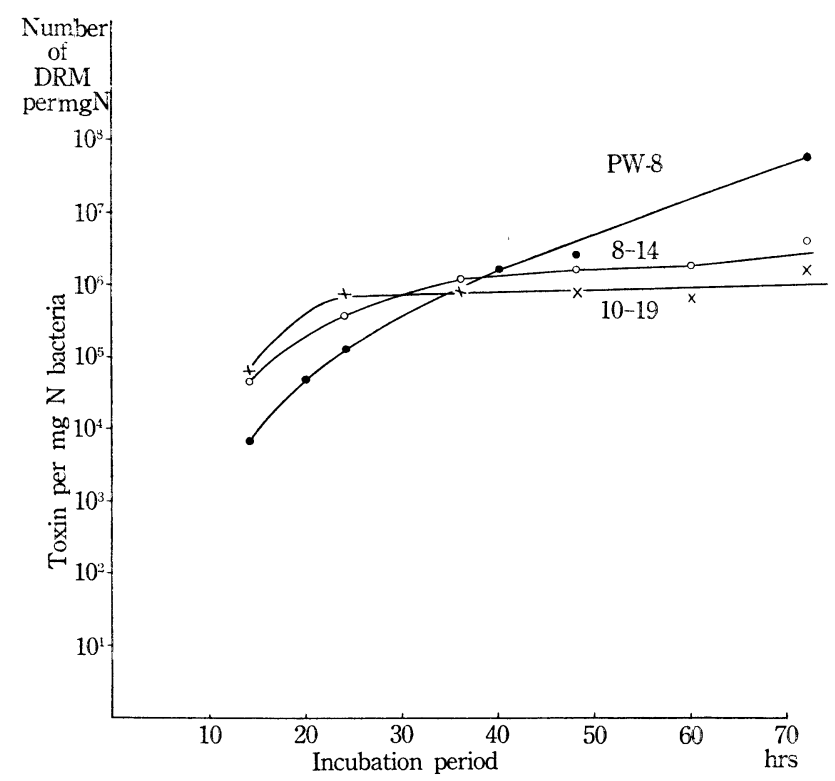

Fig. 3. Growth and toxin production of three strains in the semisynthetic medium (II).

might be difficult to relate the infectivity with the difference of the ability to produce toxin in the presence of iron.

Exp. 3. The speed of toxin production of three strains was also examined. A modified Mueller and Miller's medium was used. The inoculated tubes were incubated at $34^{\circ} \mathrm{C}$. Three tubes were removed at intervals for the examination of growth $(\mathrm{mg}$ $\mathrm{N}$ of cells) and toxin titer (DRM). The results are shown in Figs. 2 and 3 . In the long run, strain PW-8 showed the highest growth and toxin production, but in the early stages of incubation it was inferior to the other two strains in both respects. In the comparison between 10-19 and 8-14, the former seems to be better than the latter in the speed of growth and toxin production, but the difference could not be considered significant to explain the difference in the infectivity.

These results suggest that neither iron concentration nor speed of growth in vitro was able to explain, as an exact reason, the different infectivities among various strains of $C$. diphtheriae.

\section{REFERENCES}

Mueller, J. H. (1941): Toxin production as related to the clinical severity of diphtheria. J. Immunol., 42, 353-360.

Murata, R., Akama, K., Hirose, S., Kameyama, S., Nakano, T. \& Yamamoto, A. (1959) : Virulence and immunity of Corynebacterium diphtheriae. I. General pictures of infection and immunity in the conjunctival diphtheria. Jap. J. M. Sc. \& Biol., 12, 319-330. 
Department of Bacteriology II, National Institute of Health, Tokyo
KIYOTO AKAMA

SHOICHI KAMEYAMA

AKIHARU ITO

Received: December 7th, 1961.

赤真清人・亀山昭一・伊藤明治（国立予防衛生研究所細菌第二部） 